\title{
Acute disseminated encephalomyelitis presenting as optic neuritis in a case of idiopathic thrombocytopaenic purpura
}

\author{
Norman Mendonca, ${ }^{1}$ Amish J Shah, ${ }^{1}$ May Saldanha, ${ }^{1}$ Sarita R J Gonsalves ${ }^{2}$
}

'Department of Ophthalmology, Father Muller Medical College, Mangalore, Karnataka, India ${ }^{2}$ Department of Ophthalmology, Kastruba Medical College, Manipal, Karnataka, India

\section{Correspondence to} Dr Sarita R J Gonsalves, gonsalvessarita@gmail.com

Accepted 30 March 2014

\section{DESCRIPTION}

Acute disseminated encephalomyelitis (ADEM) is an uncommon monophasic inflammatory demyelinating disease that usually presents in children and young adults after viral infection. It is thought to be an autoimmune disorder of the central nervous system (CNS). ${ }^{1}$ Antiviral antibodies or a cellmediated response to the pathogen cross-react with the myelin autoantigens. Patients usually present with convulsions, paresis, altered sensorium and other signs of CNS involvement. Isolated optic neuritis as the only presenting feature of ADEM is a very rare and reported only in $2 \%$ of the cases. ${ }^{2}$

We present a child with isolated visual loss related to optic neuritis, occurring after an episode of viral illness in a diagnosed case of idiopathic thrombocytopaenic purpura (ITP).

A 7-year-old boy presented with sudden onset diminution of vision in the right eye with pain on ocular movement of 1 week duration. There were no $\mathrm{H} / \mathrm{O}$ convulsions, weakness, fever and headache.

The patient was a known case of ITP and had a history of viral fever 4 months ago. Visual acuity right eye (RE) - perception of light, accurate projection of rays. Left eye (LE)-6/6. Anterior segment examination RE showed a relative afferent pupillary defect. Fundus examination of the RE revealed disc hyperaemia and oedema, few peripapillary flame-shaped haemorrages which was suggestive of optic neuritis (figure 1). Fundus (LE) was normal (figure 2). Blood picture showed lymphocytosis,

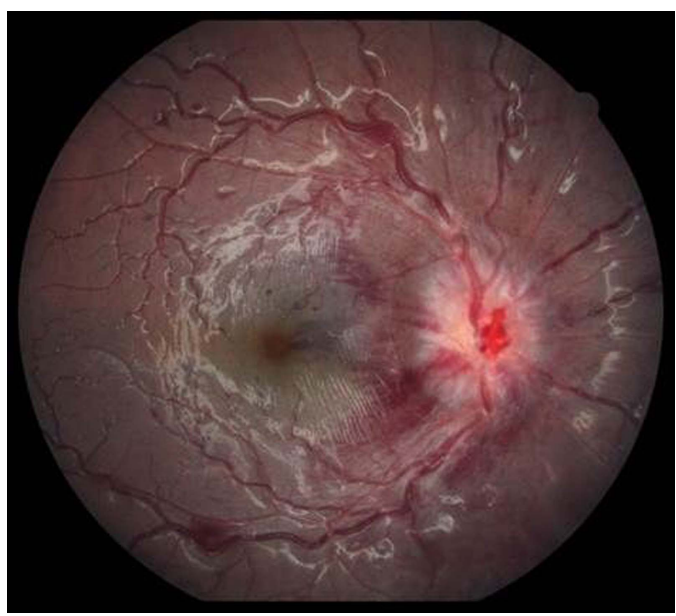

Figure 1 Fundus picture of the right eye showing disc hyperaemia, blurring of disc margins and peripapillary flame-shaped haemorrhages.

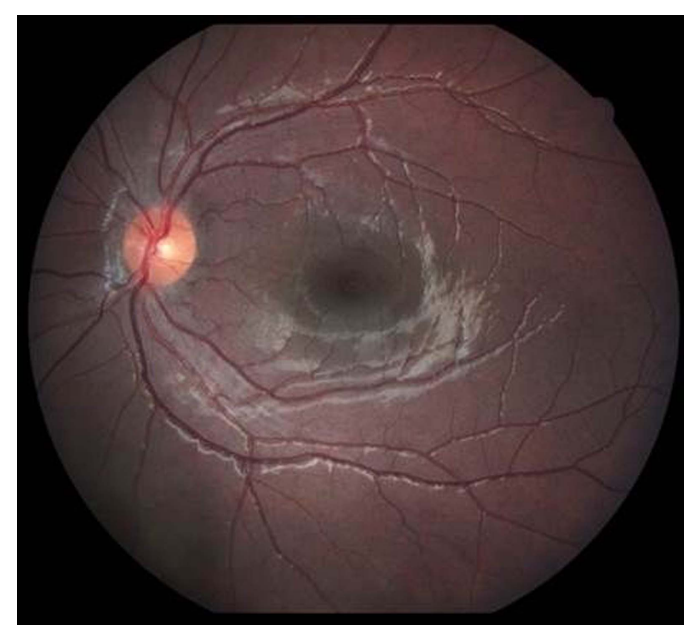

Figure 2 Left eye-normal fundus.

raised erythrocyte sedimentation rate and $\mathrm{C}$ reactive protein. Cerebrospinal fluid analysis showed pleocytosis and increased protein concentration. MRI showed features such as non-specific white matter enhancement and optic nerve enhancement (figure 3). Visually evoked potential showed prolonged latency suggestive of optic neuritis.

The patient was started on intravenous methyl prednisolone for 3 days and was then started on tapering doses of oral steroids under the guidance of paediatricians. The patient had thrombocytopaenic episodes which was promptly treated.

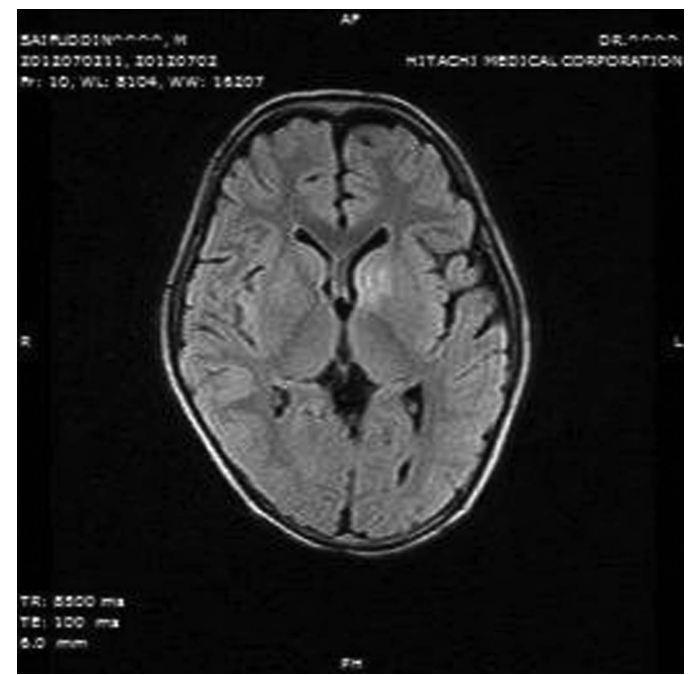

Figure $3 \mathrm{MRI}$ of the brain showing features of acute disseminated encephalomyelitis. 


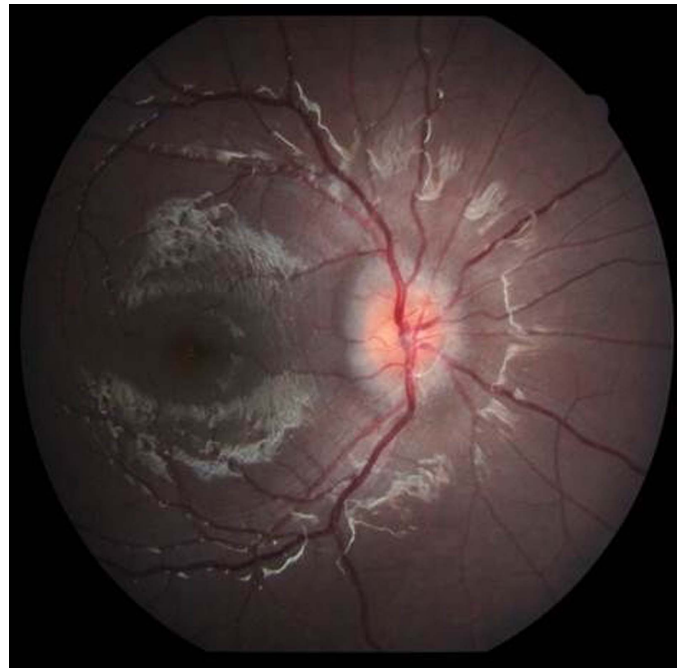

Figure 4 Resolving disc oedema.

After 3 months of follow-up the patient's vision improved to 6/36. Fundus picture showed mild persisting optic disc oedema (figure 4).

Contributors AJS was involved in data collection and compilation. SRJG was involved in drafting of the manuscript. NM and MS were involved in final approval of the manuscript.

\section{Learning points}

- Acute disseminated encephalomyelitis (ADEM) is an inflammatory syndrome affecting the central nervous system (CNS) that often is associated with parainfectious causes. Optic neuritis as an isolated manifestation is very rare.

- Visual prognosis is good in cases of optic neuritis in ADEM, once detected early and aggressively treated with intravenous steroids and immunoglobulins.

- Long-term CNS sequelae and disability was more common in patients who presented with optic neuritis. This alarms the need for an integrated approach as a team of ophthalmologists and paediatricians, for early detection, treatment and prevention of disability.

\section{Competing interests None.}

Patient consent Obtained.

Provenance and peer review Not commissioned; externally peer reviewed.

\section{REFERENCES}

1 Tantri AP, Lee AG. Acute demyelinating encephalomyelitis (ADEM) with associated optic neuritis: 9-year-old girl presents to an outside hospital with fatigue, poor appetite, and decreased activity for 3 weeks. EyeRounds.org 2005. http://www. EyeRounds.org/cases/30-AcuteDemyelinatingEncephalomyelitis.htm

2 Chan WH, Lloyd IC, Ashworth JL. Acute disseminated encephalomyelitis associated with optic neuritis and marked peri-papillary hemorrhages. Eye 2011;25:1658-9.

Copyright 2014 BMJ Publishing Group. All rights reserved. For permission to reuse any of this content visit http://group.bmj.com/group/rights-licensing/permissions.

BMJ Case Report Fellows may re-use this article for personal use and teaching without any further permission.

Become a Fellow of BMJ Case Reports today and you can:

- Submit as many cases as you like

- Enjoy fast sympathetic peer review and rapid publication of accepted articles

- Access all the published articles

- Re-use any of the published material for personal use and teaching without further permission

For information on Institutional Fellowships contact consortiasales@bmjgroup.com

Visit casereports.bmj.com for more articles like this and to become a Fellow 